\title{
Efficacy of different weed management practices and various fertility levels in soybean [Glycine max (L.) Merrill]
}

\author{
P.S. DEORE AND A.B. PATIL* \\ Department of Agronomy, Junagadh Agriculture University, JUNAGADH (GUJARAT) INDIA \\ (Email : apatil111177@ rediffmail.com)
}

\begin{abstract}
An experiment was conducted during Kharif season of 2006 as Junagadh (Gujarat) to study the efficacy of weed management practices in soybean [Glycine $\max ($ L.) Merrill] under various fertility levels. Different weed management treatments tried in this experiment exerted their significant effect on grain and stover yield of soybean. Almost all the growth and yield attributes were recorded maximum value under treatment $\mathrm{W}_{5}$. Treatment $\mathrm{W}_{4}$ was found equally effective in respect on recording higher values of these parameters than rest of the treatments. Application of 40:80:40 kg NPK ha ${ }^{-1}$ recorded the maximum value of plant height, plant spread, number of pods, seeds per pod and test weight. This reflected in marked effect in increasing grain (2006 $\left.\mathrm{kg} \mathrm{ha}^{-1}\right)$ and stover $\left(2381 \mathrm{~kg} \mathrm{ha}^{-1}\right)$ yields.
\end{abstract}

Key Words : Soybean, Pendimathalin, Quizalofop-ethyl, Imazethapyr, Fertility levels

View Point Article : Deore, P.S. and Patil, A.B. (2016). Efficacy of different weed management practices and various fertility levels in soybean [Glycine max (L.) Merrill]. Internat. J. agric. Sci., 12 (1) : 73-75.

Article History : Received : 17.09.2015; Revised : 01.12.2015; Accepted : 13.12.2015

\footnotetext{
* Author for correspondence

Department of Agronomy, Poojya Sane Guruji Vidya Prasarak Mandal's, K.V. Patel College of Agriculture, Shahada, NANDURBAR (M.S.) INDIA
} 